\title{
Analysis of the Attitudes of the Instructors towards the Use of Technology in Teaching Turkish as a Foreign Language
}

\section{Research Article}

\section{Umut BASAR ${ }^{1}$, Onder CANGAL ${ }^{2}$}

${ }^{1}$ Social Sciences University of Ankara, School of Foreign Languages, Department of Turkish, Ankara, Turkey, ORCID: 0000-0001-5571-7103

${ }_{2}^{2}$ Gaziantep University, Turkish Language Teaching, Application \& Research Center, Gaziantep, Turkey, ORCID: 0000-0002-8560-3526

To cite this article: Basar, U., \& Cangal, O. (2021). Analysis of the attitudes of the instructors towards the use of technology in teaching Turkish as a foreign language, International Online Journal of Educational Sciences, $13(1), 18-32$.

\section{ARTICLE INFO \\ Article History: \\ Received: 10.12 .2019 \\ Available online: 22.06.2020}

\begin{abstract}
Nowadays, thanks to smart devices and easy access to the internet, technological tools have become the sine qua non of human life, and people have started to do all their work through the new technological tools. Although the developments in the integration of the use of technology into foreign language teaching processes are inevitable, the attitudes of the instructors, who are the primary executors of language teaching, should be determined, and the language teaching processes should be planned accordingly. For this reason, in the study, it was aimed to determine the attitudes of those who teach Turkish as a foreign language towards the use of technology in language teaching processes, and the "Attitude Measurement Scale" developed by İpek and Kan (2019) was used to collect data. One hundred ninety-one instructors teaching Turkish as a foreign language participated in the study and SPSS.21 package program was used to analyze the data. When the analysis results have been analyzed, it has been found that the average of "avoidance value" is low, the average of "willingness value" is high and the average of "adoption value" is very high in the attitudes of the instructors towards the use of technology in classrooms. While men's avoidance scores are lower than women's, willingness and adoption scores do not differ by gender. While the avoidance scores of those who teach Turkish from one year to four years are higher than those with experience of four years or more, the willingness and adoption scores do not differ significantly from the instructors' teaching experience in Turkish.
\end{abstract}

C 2021 IOJES. All rights reserved

Keywords:

Teaching Turkish as a Foreign Language, Using Technology, Attitude [Measurement] Scale.

\section{Introduction}

Technological innovations have a direct impact on every stage of individual and social life. Within this context, one of the areas where the effect of technology advancement can be seen is the education sector.

\footnotetext{
${ }^{1}$ Corresponding author's address: Social Sciences University of Ankara, School of Foreign Languages, Departmant of Turkish

Telephone: +903125964444

e-mail: umutbasar_35@hotmail.com

DOI: https://doi.org/10.15345/iojes.2021.01.002
} 
Education, in general, and foreign language education, in particular, has created a significant change in foreign language education, from course contents to educational materials, thanks to technological advances and with the advent of the information age. For instance, four or five decades ago, foreign language education, which was used to be carried out only via printed materials, is currently conducted through various multimedia tools. Kartal (2005, p. 384), supporting this view, states that, from a historical perspective, foreign language teaching, like all other branches of science, renews itself not only in line with the conditions and requirements of its era but also with scientific progress and developing technology. It is more important to transfer technological developments to the teaching process compared to other disciplines in social sciences, especially in order to use speech and listening skills effectively in foreign language teaching. Today, the needs of individuals in learning a foreign language seem to have differentiated. While the effective use of reading and writing skills in the recent past was regarded as sufficient for learners, in today's world, however, where political boundaries began to dissolve through globalization, listening and speaking skills have also become a must, too. Thus, individuals spend considerable effort and money on learning the target language where it is spoken. For those who cannot afford the time and money to learn the target language in their native country, the innovative digital language tools help these prospective learners improve their language skills.

Drawing attention to the fact that technology has been profoundly remolding foreign language education, Freeman and Anderson (2014, p. 250), claim that computer programs can now be customized for individual learners by analyzing each student's interactive input, giving customized feedback and providing extra exercises that improve their competence. Therefore, thanks to technology, foreign language education has not been a unilateral "transfer" process towards students any more today. In support of this view, Chilingaryana and Zvereva (2017, p. 1504) suggest that the role of the teacher has been redefined in ITsupported classrooms, the role of learners, who have generally been regarded as 'passive' receivers, has altered and more responsibility is taken on by the learners in these classes, and more importantly, the interactive activities have started to be directed by the learners themselves. Furthermore, it is now possible to claim that a foreign language can be learned through various programs, even without a need for a teacher.

As a chief advantage of technology, the course contents to be used in foreign language education utilizing multimedia tools are very beneficial, since they appeal to the multiple senses of the learners. Accordingly, Günday $(2015$, p. 284$)$ lists the main benefits of using multimedia tools and materials in foreign language education as follows:

- The teacher has the opportunity to update course activities at any time.

- The opportunity to use the same materials over and over again saves time and thus being economical.

- Provides unlimited and unrestricted access to rich and effective content (Zeldman, 2001, by Erişti 2011, p. 99).

- Many exercises and different question types are readily available.

- It provides students with the opportunity to work at their own pace.

- It increases diversity in foreign language education.

- It helps to acquire information and skills via concrete examples

- It increases students' interest and motivation.

- It offers not only the acquisition of non-verbal language but also of verbal language, too.

- Virtual communication and collaboration tools help to establish authentic communication. Students who like to communicate in the target language with the native speakers have the opportunity to both practice and gain multicultural experience (Herrell, Roblyer and Jordan, 2006, p. 314).

- Learners can receive [instant] feedback.

- It ensures that teaching is learner-centered.

- It helps to realize effective and active learning. 
- Web 2.0 technologies and the Internet allow learning by offering hands-on experience.

Warschauer (2000) states that the integration of technology with foreign language education can take place in two different ways. According to him, this integration can be attained through a cognitive approach in the first place. Through technology, students' exposure to language significantly increases, and then their foreign language improves to a great extent. Secondly, this improvement can be achieved through social interaction. Students can be offered real social interaction opportunities to use their language skills. Besides, Arifah (2014, by Ahmadi 2018, p. 118) emphasizes that the use of multimedia tools will help students improve their higher-level thinking skills, and suggests that the use of technology creates meaningful learning atmosphere and increases learner's motivation.

In the course of in the [foreign language] education technologies history, you will all remember "pen pals," an outdated communicative writing practice that helped students to improve their writing skills, in particular. With the developing technology, this practice has been replaced by social media programs, which later have emerged as a more effective yet inexpensive language tool as a part of social media communication, as it focuses more on the target audience's listening and speaking skills.

Scientific research has revealed that social media applications have a positive effect on students' writing and speaking skills and on their glossary (see Teoh \& Neo, 2007; İnce, 2011; Alsaleem, 2014; Baş \& Turhan, 2017). In other words, even when technological tools are not deliberately used for educational purposes, they still contribute to language learning. On the other hand, with the inclusion of applications with planned and effective inputs in foreign language education processes, technology is thought to have significant impacts on language teaching. Therefore, this study aims to determine the attitudes of instructors, who are the leading executives of language teaching technology.

\section{Method}

In this study, aiming to determine the attitudes of Turkish instructors as a foreign language towards the use of technology, the descriptive survey model, a quantitative research method, was used. Via this model, it is aimed to describe a situation that was experienced in the past or that still exists. The subject, individual or object that is the subject of the research, should be defined as it is. No attempt is made to change the research subject whatsoever (Karasar, 2012, p. 77).

In order to collect data for the research, "The Attitude Measurement Scale for the Instructors of Turkish as a Foreign Language," developed by İpek and Kan (2019), was used. The scale, after the expert opinion, was applied to 302 people, who teach Turkish as a foreign language: As a part of Exploratory Factor Analysis (EFA), a three-factor structure titled, "avoidance," "willingness" and "adoption," consisting of 30 items of fivepoint Likert type has been decided to be implemented.

In order to verify the construct validity of items, the scale was applied to a different group of 191 people, and the construct validity of which was confirmed by performing a Confirmatory Factor Analysis (CFA) - with the data collected. The internal consistency coefficient of the scale, that is, Cronbach Alpha Value, is 0.95 for the avoidance factor; 0.91 for the willingness factor, it was calculated to be 0.89 for adoption factor, and 0.91 being the figure for the entire scale.

\section{Study Group}

The study group of the research is comprised of 191 instructors teaching Turkish as a foreign language. 29.3 percent of the participants are male, and 70.6 percent are female. The data on the educational status of the participants are as follows: 
Table 1. Education Level of the Instructors

\begin{tabular}{lcc}
\hline Level & $f$ & $\boldsymbol{\%}$ \\
\hline BA & 120 & 62,8 \\
\hline MA & 58 & 30,3 \\
\hline PhD & 14 & 7,3 \\
\hline Total & $\mathbf{1 9 1}$ & $\mathbf{1 0 0}$ \\
\hline
\end{tabular}

62.8 percent of the instructors are undergraduate, 30.3 percent are masters, and 7.3 percent being doctorate graduates. It is seen that majority of the instructors working in the field of teaching Turkish as a foreign language are undergraduate graduates. The data regarding the ages of the instructors are as follows:

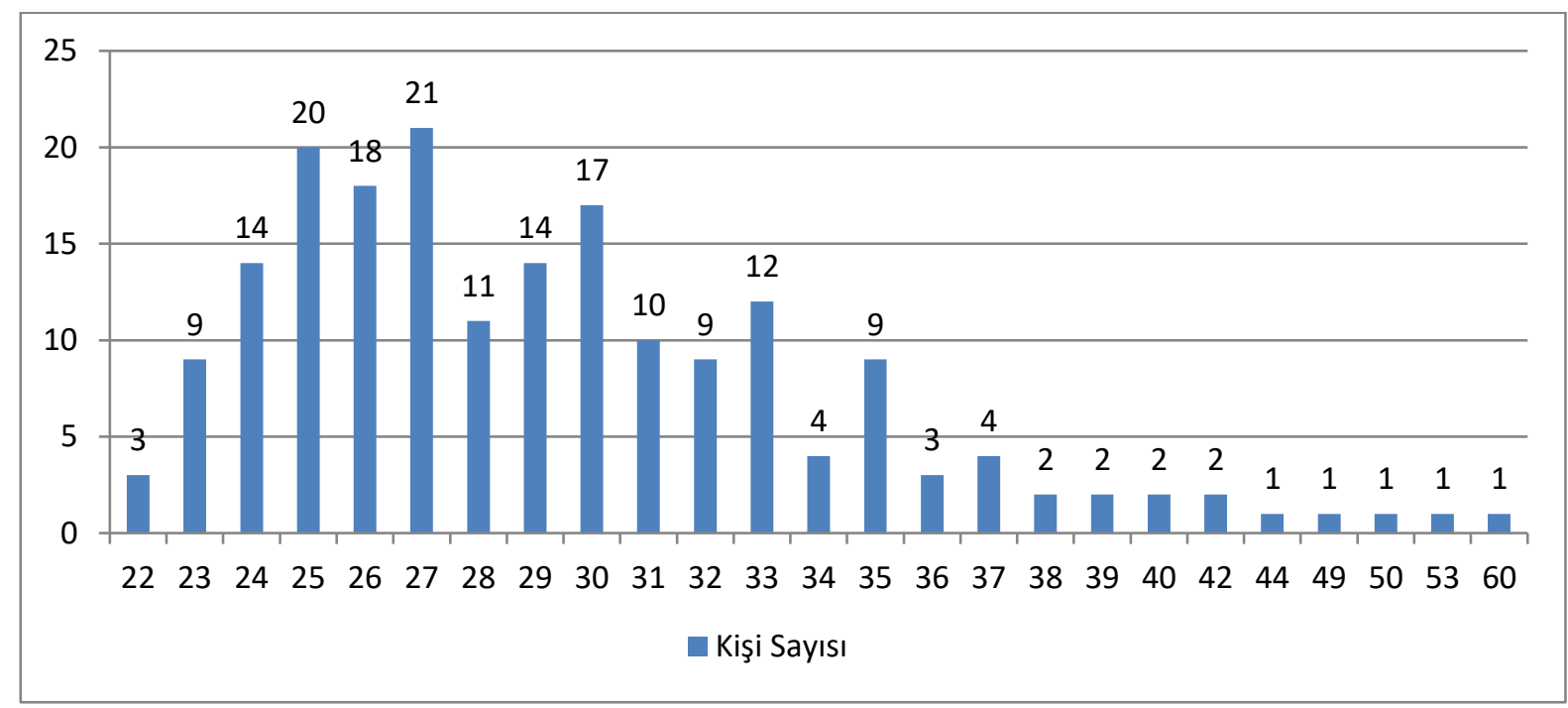

Figure 1. Age Groups

When the age groups of the instructors are examined, it is seen that the majority are between the ages of 23-35. Three of the instructors are twenty-two years old. 87.9 percent of the instructors (168 people) are between the ages of 23-35. Three of the tutors are thirty-six, and four of them are thirty-seven years old. Two subjects are in each study group for the ages of 38,39,40, and 42 . There is just one instructor for the age groups of $44,49,50,53$, and 60 .

The figures regarding the experiences of the instructors in teaching Turkish to foreigners are as follows:

Table 2.Teaching Experience

\begin{tabular}{lcc}
\hline & $f$ & $\boldsymbol{\%}$ \\
\hline Less than one year & 44 & 23 \\
\hline For one year & 29 & 15,1 \\
\hline For two years & 24 & 12,5 \\
\hline For three years & 29 & 15,1 \\
\hline For four years & 12 & 6,2 \\
\hline For five years & 6 & 3,1 \\
\hline More than five years & 47 & 24,6 \\
\hline Total & $\mathbf{1 9 1}$ & $\mathbf{1 0 0}$ \\
\hline
\end{tabular}

Twenty-three percent of the instructors have been teaching Turkish to foreigners for less than a year. 15.1 percent of the instructors teach Turkish to foreigners for a year, 12.5 percent for two years, 15.1 percent 
for three years, 6.2 percent for four years, and 3.1 percent for five years. 24.6 percent of the instructors have been working in the field for more than five years.

The data regarding the types of institutions where the instructors work are as follows:

Table 3.The Categories of the Institutions

\begin{tabular}{lcc}
\hline & $f$ & $\boldsymbol{\%}$ \\
\hline Private Language Courses & 38 & 19,8 \\
\hline State Schools (PICTES, Electives, etc.) & 60 & 31,4 \\
\hline Language Centres at Universities & 52 & 26,1 \\
\hline Yunus Emre Institute & 41 & 21,4 \\
\hline Total & $\mathbf{1 9 1}$ & $\mathbf{1 0 0}$ \\
\hline
\end{tabular}

19.8 percent of the instructors work in private courses, 31.4 percent in official schools, 26.1 percent in universities' various Research and Application Centres for Turkish Education, and 21.4 percent in the Yunus Emre Institute. Instructors working in public/state schools work in the PICTES Project, or the Teaching Turkish as a Foreign Language offered as an elective course. When the institutions for which they work are examined, it is seen that they teach Turkish to foreigners both in the home country and in the overseas countries.

In the study, the teachers were asked the question, "At which levels do you use technology the most while teaching Turkish?". The data as to the response to the question are listed below:

Table 4. Language Levels at which Educational Technologies are used

\begin{tabular}{lcc}
\hline & $f$ & $\%$ \\
\hline A1 & 178 & 38,9 \\
\hline A2 & 126 & 27,5 \\
\hline B2 & 70 & 15,3 \\
\hline C1 & 40 & 8,7 \\
\hline C2 & 29 & 6,3 \\
\hline Total & 14 & 3 \\
\hline
\end{tabular}

The 191 teachers who participated in the research gave 457 different answers to the question "At which levels do you use technology the most while teaching Turkish?" When the responses of the instructors are examined, it is seen that instructors' use of technology decreases gradually from A1 to C2. Out of all the teachers, 178 of them stated that they used technology while teaching Turkish at A1 level, 126 at A2 level, 70 at B1 level, 40 at B2 level, 29 at C1 level and 14 at C2 level.

In the study, the teachers were asked the question, "For which language skill is technology the most useful in improving a foreign language?" The data for the answer to the question is as follows:

Table 5. Language Skills Technology is benefited from

\begin{tabular}{lcc}
\hline & $f$ & $\boldsymbol{\%}$ \\
\hline Reading & 18 & 9,4 \\
\hline Listening & 128 & 67 \\
\hline Speaking & 38 & 19,8 \\
\hline Writing & 7 & 3,6 \\
\hline Total & $\mathbf{1 9 1}$ & $\mathbf{1 0 0}$ \\
\hline
\end{tabular}


According to the instructors, the language skill that the use of technology is most beneficial is "listening" (67\%). Listening is followed by the skill of "speaking" (19.8\%), "reading" (9.4\%), and "writing" (3.6\%), respectively.

Four hundred eighty-nine different answers were received from the instructors to the question, “Which technological devices and tools do you use in your lessons?" The data as to the responses by the instructors are as follows in the table below:

Table 6. Technological Tools employed

\begin{tabular}{lcc}
\hline & $f$ & $\%$ \\
\hline Smart [White] Boards & 79 & 16,1 \\
\hline Teaching Turkish Online Portal & 34 & 6,9 \\
\hline E-books & 80 & 16,3 \\
\hline Computers & 159 & 32,5 \\
\hline OHP & 131 & 26,7 \\
\hline Printers & 1 & 0,2 \\
\hline Photocopies & 2 & 0,4 \\
\hline Smart Phones & 3 & 0,6 \\
\hline Total & $\mathbf{4 8 9}$ & $\mathbf{1 0 0}$ \\
\hline
\end{tabular}

Out of all the instructors who responded to the questionnaire, 159 expressed that they use computers, 131 of whom use projections, 80 of whom benefit from electronic books, 79 of whom use smart boards, and 34 of them benefitting from the online Turkish teaching portal in their lessons. Electronic books; It allows Turkish teaching sets to be used via smart boards or projection devices. Electronic books (e-books) are also called "multimedia e-books." While teaching Turkish to foreigners, three of the teachers stated that they use smartphones, two of them using a photocopy, and one of them uses a printer in their teaching.

\section{Data Collection and Analysis}

"The Attitude Measurement Scale for the Instructors of Turkish as a Foreign Language," developed by İpek and Kan (2019), has been filled out via Google Forms and has been sent to the teachers' email accounts, who all work in the field of teaching Turkish as a foreign language, enclosed with a detailed explanation of the scale.

During the analysis of the collected data, firstly, positive, and negative items in the scale were determined. In order to reveal the teachers' attitudes towards technology, the scores obtained from the scale were given the reversing "scale value codes" in contrast to the items with a positive value. Accordingly, these items in the scale were scored as "disagree" 1, "I agree" 5, while the items with a negative value were scored "disagree" 5, "I agree" 1.

In the analysis of the data obtained; statistical analyses such as arithmetic mean, correlation and t-test were implemented using the SPSS 21.0 program. Multiple comparison test technique ANOVA was used to determine whether the attitudes of the teachers towards the use of technology differ amongst the groups in determining the relationship between the scores of the participants as to the dimensions of the scale. In addition, arithmetic mean scores were used to determine the mean scores of the teachers' attitude scale scores. The findings collected as a result of the analyzes are interpreted together with the data in the literature and thus some suggestions have been presented. 


\section{Findings}

Within the scope of the study, the attitudes of those who teach Turkish as a foreign language towards technology were examined. In the study, the Cronbach Alpha reliability coefficient is 0.91 . This result shows that the scale implemented is reliable.

The attitude [measurement] scale in this study consists of three factors: avoidance, willingness, and adoption. In practice, the responses given to the items were examined according to their frequency distributions and the participants' age, gender, educational background, experience in teaching Turkish, and the institutions where they teach Turkish.

Average attitude scores of the participants towards technology are as follows:

Table 7. Average Attitude Scores of the Participants towards Technology

\begin{tabular}{lcccccc}
\hline & $\mathbf{n}$ & $\mathbf{M}$ & SD & Min. & Max. & Alpha \\
\hline Avoidence & 191 & 1,616 & 0,610 & 1,000 & 4,670 & 0,919 \\
\hline Willingness & 191 & 4,028 & 0,733 & 1,000 & 5,000 & 0,918 \\
\hline Adoption & 191 & 4,354 & 0,712 & 1,000 & 5,000 & 0,954 \\
\hline
\end{tabular}

Considering Table 7, the average of "avoidance" of the teaching staff is very low $1.616 \pm 0.610$ (Min $=1$; Max =4.67), whereas the average of "willingness" is high $4.028 \pm 0.733$ (Min = 1; Max =5), and the "adoption" average is found to be very high high $4.354 \pm 0.712$ ( $\operatorname{Min}=1$; $\operatorname{Max}=5)$.

"With the increase in computer use, there has been an increase in the use of devices such as smartphones, tablets, and smart televisions, and internet technologies that help improve these devices and establish a connection with the world have continued to develop year by year" (Çangal, 2019, p. 181). Along with the developments in internet technologies, the use of technological tools in language teaching processes is gaining importance day by day. When the answers given by the instructors working in the field are examined, it is seen that the teachers do not avoid using technology; on the contrary, the use of technological tools is largely adopted by the teachers, and they are willing to use technology in language teaching processes.

In order to reveal the relationship between the factors, the responses given were subjected to correlation analysis. The correlation between attitudes towards technology scores is as follows:

Table 8. The Correlation between Attitudes towards Technology Scores

\begin{tabular}{ccccc}
\hline & & Avoidance & Willingness & Adoption \\
\hline \multirow{2}{*}{ Avodience } & $\mathrm{r}$ & 1,000 & & \\
\cline { 2 - 5 } & $\mathrm{p}$ & 0,000 & 1,000 & \\
\hline Willingness & $\mathrm{r}$ & $-0,292^{* *}$ & 0,000 & 1,000 \\
\cline { 2 - 5 } & $\mathrm{p}$ & 0,000 & $0,776^{* *}$ & 0,000 \\
\hline Adoption & $\mathrm{r}$ & $-0,288^{* *}$ & 0,000 & \\
& $\mathrm{p}$ & 0,000 & & \\
\hline
\end{tabular}

${ }^{*}<0,05 ;{ }^{* *}<0,01$

When the correlation analysis between technology attitude scores in Table 8 is analyzed; $r=-0.292$ negative $(p=0.000<0.05)$ between willingness and avoidance, $r=-0.288$ negative $(p=0,000<0.05)$ between adoption and avoidance, $r=0.776$ positive $(p=0,000<0.05)$ relationship has been found.

When the instructors' responses regarding the use of technology are examined, it is seen that the teachers who have adopted the technology are also willing to use technology similarly. This result also explains the positive relationship between adoption and willingness attitudes. When the table is examined in terms of avoidance factor, it can be thought that the instructors who adopt and are willing to use technology 
do not refrain from using technology, and those who refrain from using technology are not able to adopt technology and are not willing to use technology in language teaching processes.

Finally, in the study, the attitudes of the instructors towards the use of technology in language teaching processes were compared in line with their age, gender, educational background, Turkish teaching experience, and where they teach Turkish. Data regarding the differentiation of technology attitude scores according to descriptive characteristics are as follows:

Table 9. Differences in Attitude Scores of Instructors towards Technology by their Descriptive Features

\begin{tabular}{|c|c|c|c|c|}
\hline Demographic Features & $\mathbf{n}$ & Avoidance & Willingness & Adoption \\
\hline Age & & $\bar{X}_{ \pm \mathrm{SD}}$ & $\bar{X}_{ \pm \mathrm{SD}}$ & $\bar{X}_{ \pm \mathrm{SD}}$ \\
\hline 25 and Under & 46 & $1,661 \pm 0,633$ & $4,157 \pm 0,608$ & $4,508 \pm 0,505$ \\
\hline $26-30$ & 81 & $1,656 \pm 0,665$ & $3,928 \pm 0,840$ & $4,255 \pm 0,885$ \\
\hline 36 and Over & 64 & $1,533 \pm 0,514$ & $4,061 \pm 0,657$ & $4,369 \pm 0,568$ \\
\hline $\mathrm{F}=$ & & 0,903 & 1,530 & 1,897 \\
\hline $\mathrm{p}=$ & & 0,407 & 0,219 & 0,153 \\
\hline Gender & & $\bar{X}_{ \pm} \mathrm{SD}$ & $\bar{X}_{ \pm \mathrm{SD}}$ & $\bar{X}_{ \pm \mathrm{SD}}$ \\
\hline Male & 56 & $1,499 \pm 0,428$ & $4,064 \pm 0,804$ & $4,384 \pm 0,729$ \\
\hline Female & 135 & $1,665 \pm 0,666$ & $4,013 \pm 0,704$ & $4,342 \pm 0,708$ \\
\hline$t=$ & & $-1,725$ & 0,443 & 0,372 \\
\hline$p=$ & & 0,042 & 0,658 & 0,710 \\
\hline Education & & $\bar{X}_{ \pm \mathrm{SD}}$ & $\bar{X}_{ \pm \mathrm{SD}}$ & $\bar{X}_{ \pm \mathrm{SD}}$ \\
\hline BA & 120 & $1,665 \pm 0,684$ & $4,071 \pm 0,715$ & $4,413 \pm 0,661$ \\
\hline MA & 71 & $1,533 \pm 0,450$ & $3,955 \pm 0,761$ & $4,255 \pm 0,787$ \\
\hline$t=$ & & 1,455 & 1,057 & 1,479 \\
\hline$p=$ & & 0,147 & 0,292 & 0,141 \\
\hline Experience & & $\bar{X}_{ \pm \mathrm{SD}}$ & $\bar{X}_{ \pm \mathrm{SD}}$ & $\bar{X}_{ \pm \mathrm{SD}}$ \\
\hline Less than 1 year & 44 & $1,633 \pm 0,683$ & $3,961 \pm 0,818$ & $4,327 \pm 0,911$ \\
\hline 1-4 Years & 82 & $1,731 \pm 0,666$ & $4,045 \pm 0,690$ & $4,358 \pm 0,572$ \\
\hline More than 4 years & 65 & $1,460 \pm 0,432$ & $4,051 \pm 0,734$ & $4,367 \pm 0,731$ \\
\hline $\mathrm{F}=$ & & 3,690 & 0,234 & 0,045 \\
\hline $\mathrm{p}=$ & & 0,027 & 0,792 & 0,956 \\
\hline PostHoc= & & $2>3(\mathrm{p}<0.05)$ & & \\
\hline Institution & & $\bar{X}_{ \pm S D}$ & $\bar{X}_{ \pm \mathrm{SD}}$ & $\bar{X}_{ \pm \mathrm{SD}}$ \\
\hline Yunus Emre Institute & 41 & $1,547 \pm 0,484$ & $3,944 \pm 0,783$ & $4,390 \pm 0,727$ \\
\hline Private Courses & 38 & $1,540 \pm 0,443$ & $4,042 \pm 0,748$ & $4,405 \pm 0,485$ \\
\hline University Language Centers & 52 & $1,609 \pm 0,684$ & $4,127 \pm 0,697$ & $4,349 \pm 0,707$ \\
\hline State Schools & 60 & $1,718 \pm 0,702$ & $3,990 \pm 0,726$ & $4,302 \pm 0,831$ \\
\hline $\mathrm{F}=$ & & 0,938 & 0,551 & 0,204 \\
\hline $\mathrm{p}=$ & & 0,424 & 0,648 & 0,894 \\
\hline
\end{tabular}

When the age groups of the participants are examined, it is seen that there are 46 people aged 25 and below, 81 people aged 26-30 and 64 people aged 36 and over. When we look at whether the ages of the academic staff affect their attitudes towards technology, it is seen that the avoidance, willingness, and adoption scores of the academic staff do not differ significantly according to the age variable $(p>0.05)$.

When the attitudes of the participants towards technology are analyzed according to the gender variable, the avoidance scores of men who constitute 29.3 percent of the total number of teachers participating 
in the research $(x=1,499)$, and the avoidance scores of women who make up 70.6 percent of the total number of teachers participating in the research $(x=1.665)$, were found to be statistically low $(t=-1.725 ; p=0.042<0.05)$. In other words, according to these data, female teachers avoid using technology more than men. The willingness and adoption scores of instructors do not differ significantly according to gender $(p>0.05)$.

While 62.8 percent of the teachers participating in the research state they have a bachelor's degree, the remaining 37.2 percent are comprised of people who have completed their masters and doctorates. The avoidance, willingness and adoption scores of the academic staff do not differ significantly according to their education level variable $(\mathrm{p}>0.05)$.

Out of the teachers that taught Turkish to foreigners for less than a year, 44 participated in the study. However, there are 82 people with one to four years of experience and 65 people with four years of experience. The avoidance scores of the academic staff show a significant difference when examined according to how many years the Turkish language is taught $(\mathrm{F}=3,690 ; \mathrm{p}=0.027<0.05)$. The reason for the difference is that the avoidance scores of those who teach Turkish for one to four years are higher than those of those who teach Turkish for more than four years $(\mathrm{p}<0.05)$. The reason for this situation may be that experienced teachers can benefit from technological tools more efficiently and effectively in the process. Apart from this, the willingness and adoption scores of faculty members do not differ significantly according to the experience in teaching Turkish ( $\mathrm{p}>0.05)$.

Finally, in the table above, there are data regarding the places where the instructors work. Forty-one of the instructors work in Yunus Emre Enstitüsü, 38 in private language courses, 52 in language centers of universities, and 60 in public schools. When the attitudes of the instructors about their positions and factors are examined, it is understood that the avoidance, willingness, and adoption scores of the teaching staff do not differ significantly according to the variable as to where Turkish is taught $(p>0.05)$.

\section{Discussion and Conclusion}

Technological developments affect human life and make daily life easier; thanks to the technological tools, blended learning models have begun to guide teaching models. "It is seen that blended learning environments are used to acquire cognitive skills and make significant contributions to grasping these [new] skills" (Dikmenli and Ünaldı, 2013, p. 329). The developments in education are not limited to this only, and interest in distance / online education is increasing day by day. Many institutions and organizations open distance education programs as an alternative to regular/formal education, thus enabling people to gain access to information without time and space restrictions.

The Committee of Ministers of the Council of Europe has set the goal of differentiating and intensifying language teaching in order to develop modern language teaching methods and promote multilingualism in Europe. In this context, it emphasized the use of all new communication and information technologies in the development of communication and information exchange in education systems (Telc, 2013, p. 13). The Committee also asked the academics to prepare the Common European Framework of Reference for Languages in order to contribute to the systematic, standard and contemporary implementation of education.

Today, keeping up with the developing technologies can only be accomplished through adapting to the rapid pace of the information age. Information has been constantly being updated, and its structure being altered. In this global village in which we live now, the rapid access to information in has become an indication of the development and superiority level of the countries. States that seek to be the best in all fields strive hard to improve their education systems to be the leaders in this race (Korkmaz, 2011, p. 20).

Today, importance is attached to improving the physical facilities of the classrooms both in public and private schools, and internet, computers, overhead projectors and smart boards are provided to help improve 
the education quality in the classrooms. Improving the physical conditions of classes improves the quality of teaching, which directly affects student success. Şensoy and Sağsöz $(2015$, p. 97) also stated that it is important to improve the physical conditions of educational facilities in increasing student achievement, and thus if the educational environments and conditions are improved, the motivation, success, social interaction and responsibility perception of the learners will be positively affected.

Although it is important to bear in mind that the physical facilities in schools, universities and language teaching centres comply with the requirements and demands of the technology age, it is also vital that the teachers who design and practise their own teaching should be able to adapt to technological developments and be capable of implementing technological tools into their teaching processes. As one of the conclusions of their study carried out on classroom teachers, Saracaloğlu et al. $(2017$, p. 831) stated that as the experience of pre-service teachers increased in internet and computer use, they began to develop a positive attitude towards using these tools in an educational context, and when the use of technology is well planned, they claim that this becomes a helpful tool as a sort of resource for data collection. Besides, in this study, it is underlined that formal and informal learning environments should be reorganized in accordance with the current education programs in order for teachers to be able to use technology effectively.

Russel et al. (2003, p. 307) found that teachers' attitudes and beliefs towards technology are of great importance in their decision to adopt and use technology in the classroom. Therefore, in this study; the attitudes of the teachers who teach Turkish as a foreign language towards the use of technology in language teaching are examined, and also the situations, such as whether the teachers adopt the use of technology, and whether they are willing to use or prefer to refrain from using technological tools while teaching the language have been studied, too. According to the results of the study, the average of the technology avoidance value of the instructors is low, the average of the willingness value is high, and the average of the adoption value is found to be very high. Similarly, it was found out in the research - conducted by Özdemir and Taç (2017, p. 6) in order to determine the attitudes of candidate elementary school teachers towards technology - that the participants have a high positive attitude towards using technology in their classrooms.

The computer is one of the most essential technological tools used in teaching. Therefore, it is thought that attitudes of teachers towards the use of computers in education will also reveal the attitudes of teachers towards technology. In his study, Erkan (2004, p. 142) revealed that the attitudes of the educators towards computer use in classrooms were highly positive. In a similar study conducted by Lehimler (2016), it has been determined that the attitudes of candidate music teachers towards computer-assisted teaching are positive and their self-efficacy perceptions towards computer-assisted teaching are at a significant level. According to the research, it was found out that if the pre-service teachers own computers, and if they frequently use their computers, this affects the attitudes of the candidates towards computer-assisted education. In another study conducted by Kalemoğlu Varol (2014), it was found that the attitudes of physical education teachers towards educational technologies and their self-efficacy perceptions towards computer use were high. Başarıcı and Ural (2009) examined the attitudes of the candidate computer teachers towards computer-assisted education and found that the candidates' attitudes towards computer-assisted education are significantly high. In the study carried out by İpek and Acuner (2011) with the participation of candidate elementary teachers, it was found that the attitudes of the candidates towards educational technologies are quite high. In studies conducted on teachers working on different subjects, it is observed that the attitudes of the teachers towards technology and computer use are positive and in this context, it is thought that the teachers think that that it is good to use technology in teaching.

Similar results were obtained in the study conducted by Şahin and Arslan Namlı (2018) in order to determine the ideas of prospective teachers who would graduate from Çukurova University, Faculty of Education regarding the use of technological tools and equipment in education. In the study carried out with 
the participation of three hundred pre-service teachers, it was stated that the attitudes of the participants towards the use of technology in education were moderately positive. This study, which includes many subject teachers such as science, English, French, German, preschool, psychological counselling and guidance, primary school, social sciences, philosophy, art and Turkish, is regarded as crucial in that it indicates these teachers' attitudes towards use of technology in their classrooms. When the results of both this study and similar studies are taken into consideration, it is seen that the teachers are not only willing to use technological tools, but also eager to adopt the use of technology and then implement it in their classes.

In the research, it was seen that female teachers refrain from using technology more than men do, and inexperienced teachers are warier in technology use compared to experienced teachers in the field. Similarly, Özdemir and Taç $(2017$, p. 6) state that gender affects the candidate elementary teachers' attitude towards technology, and men have a more positive attitude towards the use of technology compared to their female colleagues. Arslan (2008, p. 108) in his study, which is one of the similar studies examining the relationship between attitude and self-efficacy, concluded that if there is a positive increase in the perception of selfefficacy, the attitude will similarly increase, and in case of a decrease, the other will indicate a decrease, too. From this point of view, it can be inferred that there will be a similarity between the teachers' attitudes towards technology and their self-efficacy. In the study carried out by İpek and Acuner (2011, p. 36), computer selfefficacy beliefs of male teacher candidates were higher than those of female teachers. Therefore, it can be concluded that the work performed by İpek and Acuner (2011) supports the study aforementioned. However, in the study conducted by Saracaloğlu et al. (2017, p. 831), it is indicated that, although there is no significant difference between them, the attitudes of women towards computer self-efficacy and internet use are relatively higher than those of men. Şimşek and Yıldırım (2016, p. 637) also found that there was no significant relationship between the attitudes towards the use of technology in teaching according to gender, and women seem to have more positive and higher attitude scores when the average scores are taken into account.

The inclusion of technology in teaching enables teachers to carry out language teaching more effectively. Teachers who are aware of this are willing to use technology in their teaching. "In interactive learning environments, in which technological tools are included, both teachers and students need to know how to benefit from instructional technologies and learning/teaching should be consciously realized. To that end, it is noteworthy that teachers are systematically trained at the very beginning of their undergraduate education, and then it is also central to carry out awareness-raising studies for their students." (Çangal, 2019, p. 180)

Although the use of technology is important in language teaching, another important issue is how teachers can use technology-based materials in their teachings. It can be thought that the teachers who have used the traditional methods in language teaching can not easily switch to new multimedia tools. However, it can be seen that technological developments have become an important part of not only language teaching specifically, but also education in general. For this reason, educational technology courses are included in both undergraduate programs and also in teaching formation and certificate programs. This also applies to the field of teaching Turkish to foreigners. There are lessons on technology use in foreign language education, and there is a significant increase in academic publications on how to incorporate technology into the Turkish language teaching. Although it is not sufficient in number for the time being now, in the field of teaching Turkish to foreigners, the new tools such as social media applications, distance education portals, movies and music, language laboratories, learning management systems (LMSs), web applications, podcasts, blogs, etc. are used (see Reddi, 2003; Grosseck \& Holotescu, 2008; Schuster, 2010; Kanğ, 2015; Özdemir, 2017; Yunus Emre Institute, 2018).

Tatli and Akbulut (2017, p. 49), in their study, stated that the curriculum in education faculties should be restructured, that lessons related to subjects like technology-supported material design, etc. should be added to the curriculum, and also in-service training programs should be organized for the novice teachers 
who just started teaching. In the study, it is also stated that the in-service training to be held can help reduce the number of teachers weaker in the use of technology in their classes and that the education can be kept upto-date with similar training to be carried out in the next stages.

Undoubtedly, in the field of language teaching, in-service training programs should be organized to increase the quality and content of the material production and also to determine the attitudes of the teachers towards the use of technology and to bring new technologies to their teaching. In this way, it is thought that the attitudes of those who will teach Turkish as a foreign language towards technology use will change positively in the process, and that teaching will become more modern, learning will be retained better, and success rate of the learners will increase in the same way. 


\section{REFERENCES}

Ahmadi, M. R. (2018). The use of technology in English language learning: a literature review. International Journal of Research in English Education, 3(2), 116-125.

Alsaleem, B. I. A. (2014). The effect of "WhatsApp" electronic dialogue journaling on improving writing vocabulary word choice and voice of EFL undergraduate Saudi Students. Harvard: 21st Century Academic Forum Conference Proceedings.

Arifah, A. (2014). Study on the use of technology in ELT classroom: Teachers' perspective. Unpublished Master's Thesis, Department of English and Humanities, BRAC University, Dhaka, Bangladesh.

Arslan, A. (2008). Öğretmen adaylarının bilgisayar destekli eğitim yapmaya yönelik tutumları ile öz yeterlik algıları arasındaki ilişki. Elektronik Sosyal Bilimler Dergisi, 7(24), s. 101-109.

Baş, B. ve Turhan, O. (2017). Yabancılara Türkçe öğretiminde yazma becerisine yönelik web 2.0 araçları: Poll everywhere örneği. Mersin Üniversitesi Eğitim Fakültesi Dergisi, 13(3), 1233-1248.

Başarıcı, R. ve Ural, A. (2009). Bilgisayar öğretmen adaylarının bilgisayar destekli eğitime yönelik tutumları. International Online Journal of Educational Sciences, 1(1), 165-176.

Chilingaryana, K. \& Zvereva, E. (2017). Methodology of flipped classroom as a learning technology in foreign language teaching. Procedia Social and Behavioral Sciences, (237), 1500-1504.

Çangal, Ö. (2019). Teknoloji tabanlı yabancı dil olarak Türkçe öğretimi. Emrah Boylu ve Latif Iltar (Ed), Yabancı dil olarak Türkçe öğretimi: politika, program, yöntem ve öğretim içinde (s. 169-214). Ankara: Pegem Akademi.

Dikmenli, Y. ve Ünaldı, Ü. E. (2013). Harmanlanmış öğrenme ve sanal sınıfa dönük öğrenci görüşleri. Amasya Üniversitesi Ĕ̆itim Fakültesi Dergisi, 2(2), 326-347.

Erkan S. (2004). Öğretmenlerin bilgisayara yönelik tutumları üzerine bir inceleme. Manas Üniversitesi Sosyal Bilimler Dergisi, (12), 141-145.

Erişti, S. D. (2011). Çoklu ortam uygulamalarında görsel tasarım. Ö. Ö. Dursun ve H. Ferhan Odabaşı (Ed), Çoklu Ortam Tasarımı içinde (s. 97-121). Ankara: Pegem Akademi.

Freeman, L. D. ve Anderson, M. (2014). Dil öğretiminde teknik ve ilkeler (Çev. Mehrali Calp, 3. Baskı). Ağrı: Ağrı İbrahim Çeçen Üniversitesi Yayınları.

Grosseck, G. \& Holotescu, C. (2008). Can we use Twitter for educational activities? The 4th International Scientific Conference eLSE "eLearning and Software for Education", Bucharest, April 17-18, 2008. Web: https://www.researchgate.net/publication/228685205 Can we use Twitter in educational activities adresinden 24 Ocak 2020 tarihinde alınmıştır.

Günday, R. (2015). Yabancı dil öğretiminde yaklaşımlar, yöntemler, teknikler ve multimedya araç ve materyalleri. Ankara: Favori Yayınları.

Herrell, A. L., Roblyer, M. D. and Jordan, M. (2006). Technology in English language learning and foreign instruction. M. D. Robluer (Ed), Integrating educational technology into teaching (s. 307-322). Upper Saddle River, Nj: Pearson Prentice Hall.

İnce, M. (2011). Web 2.0 teknolojileri kullanımının farklı öğrenme stillerine sahip öğrencilerin İngilizce yazma becerilerine etkisinin incelenmesi. Yayımlanmamış yüksek lisans tezi, Zonguldak Karaelmas Üniversitesi Sosyal Bilimler Enstitüsü, Zonguldak.

İpek, C., ve Acuner, H. Y. (2011). Sınıf öğretmeni adaylarının bilgisayar öz-yeterlik inançları ve eğitim teknolojilerine yönelik tutumları. Ahi Evran Üniversitesi Eğitim Fakültesi Dergisi, 12(2), 23-40. 
İpek, S. ve Kan, A. (2019). Türkçeyi yabancı dil olarak öğretenlerin teknolojiye yönelik tutumlarının belirlenmesine ilişkin bir ölçek geliştirme çalışması. International Journal of Language Academy, 7(4), 107123.

Kalemoğlu, Varol, Y. (2014). The relationship between attitudes of prospective physical education teachers towards education technologies and computer self-efficacy beliefs. The Turkish Online Journal of Educational Technology, 13(2), 157-167.

Kanğ, S. (2015). Yabancı dil olarak Türkçe kelime öğretiminde eğitim teknolojilerini kullanma. Dede Korkut Uluslararası Türk Dili ve Edebiyatı Araştırmaları Dergisi, (7), 73-84.

Karasar, N. (2012). Bilimsel araştırma yöntemleri. Ankara: Nobel Yayıncılık.

Kartal, E. (2005). Bilişim-iletişim teknolojileri ve dil öğretim endüstrisi. Uludağ Üniversitesi Ĕ̆gitim Fakültesi Dergisi, 17(2), 383-393.

Korkmaz, A. (2011). Ortä̈ğretim okullarında interaktif öğretimin model bir ders üzerinde incelenmesi. Yayımlanmamış yüksek lisans tezi, Kilis 7 Aralık Üniversitesi Fen Bilimleri Enstitüsü, Kilis.

Lehimler, E. (2016). Müzik öğretmeni adaylarının bilgisayar destekli öğretime ilişkin tutum ve öz-yeterlik algilarının incelenmesi. Turkish Studies, 11(14), 441-456.

Özdemir, O. (2017). Türkçe öğretiminde dijital teknolojilerin kullanımı ve bir web uygulaması örneği. Turkish Studies, 12(4), 427-444.

Özdemir, U. ve Taç, İ. (2017). Sınıf öğretmeni adaylarının teknolojiye yönelik tutumlarının belirlenmesi. International Primary Educational Research Journal, 1(1), 1-7.

Reddi, U., V. (2003). Multimedia as an educational tool. Usha, V. Reddi \& Sanjaya, Mishra (Ed), Educational multimedia: a handbook for teacher-developers (s. 3-8). Printed: Graphic Shield, New Delhi.

Russell, M., Bebell, D., O'Dwyer, L., \& O'Connor, K. (2003). Examining teacher technology use: Implications for preservice and inservice teacher preparation. Journal of teacher Education, 54(4), 297-310.

Saracaloğlu, A. S., Dinçer, B. ve Dedebali, N. C. (2017). Sınıf öğretmeni adaylarının internet ve teknolojiye yönelik tutumları ile bilgisayar öz yeterlik algılarının incelenmesi. Uluslararası Sosyal Araştırmalar Dergisi, 10(51), 824-832.

Schuster, H. (2010). The use of Google services and tools in academic instutions - A critical review. International Review of Law, Computers \& Technology, 24(1), 17-24.

Şahin, M. C. ve Namlı, Arslan, N. (2019). Öğretmen adaylarının eğitimde teknoloji kullanma tutumlarının incelenmesi. Türkiye Sosyal Araştırmalar Dergisi, 23(1), 95-112.

Şensoy, S. A. ve Sağsöz, A. (2015). Öğrenci başarısının sınıfların fiziksel koşulları ile ilişkisi. Ahi Evran Üniversitesi Kırşehir Ĕ̆itim Fakültesi Dergisi (KEFAD), 16(3), 87-104.

Şimşek, Ü ve Yıldırım, T. (2016). Sosyal bilgiler öğretmen adaylarının eğitimde teknoloji kullanımına ilişkin tutum ve görüşleri. Journal of Human Sciences, 13(1), 632-649.

Tatlı, Z., ve Akbulut, H. İ. (2017). Öğretmen adaylarının alanda teknoloji kullanımına yönelik yeterlilikleri. Ege Eğitim Dergisi, 18(1), 31-55.

Telc (2013). Diller için Avrupa ortak öneriler çerçevesi -öğrenim, öğretim ve değerlendirme. Frankfurt, Germany: Telc GmbH.

Teoh, B. S-P. \& Neo, T-K. (2007). Interactive multimedia learning: students' attitudes and learning impact in an animation course. The Turkish Online Journal of Educational Technology - TOJET, 6(4), 28-37. 
Warschauer, M. (2000). The death of cyberspace and the rebirth of CALL. English Teachers' Journal, 53, 61-67.

Yunus Emre Enstitüsü (2018). Yunus Emre Enstitüsü Türkçe Öğretim Portali hakkımızda. Web: https://learnturkish.com/tr/Sayfa/Hakkimizda/551 adresinden 26 Ocak 2020 tarihinde alınmıştır.

Zeldman, J. (2001). Taking your talent to the Web: Making the transition from graphic design to Web design. Indianapolis: New Riders. 